\title{
Diversity and Range of Amphibians of the Yukon Territory
}

\author{
Brian G. Slough ${ }^{1}$ and R. LeE MenNell ${ }^{2}$ \\ 135 Cronkhite Road, Whitehorse, Yukon Territory Y1A 5S9 Canada \\ ${ }^{2}$ P.O. Box 10002, Whitehorse, Yukon Territory Y1A 7A1 Canada
}

\begin{abstract}
Slough, Brian G., and R. Lee Mennell. 2006. Diversity and range of amphibians of the Yukon Territory. Canadian Field-Naturalist 120(1): 87-92.
\end{abstract}

\begin{abstract}
Four amphibian species occur in the Yukon: Western Toad (Bufo boreas; first verified record in 1961), the Boreal Chorus Frog (Pseudacris maculata, first record in 1995), the Columbia Spotted Frog (Rana luteiventris, first record in 1993), and the Wood Frog (Rana sylvatica; first record in 1933). The Western Toad is restricted to the Liard Basin in five geographically separated areas. Breeding sites have been located on the lower Coal River and vicinity. The Boreal Chorus Frog has been documented from a small area of the lower La Biche River valley near the Yukon-British Columbia-Northwest Territories border. The Columbia Spotted Frog occurs in two widely separated areas, at Bennett Lake in the southwest and in the Liard Basin in the southeast. The Wood Frog is widespread below treeline. Limited survey efforts continue to hinder our knowledge of amphibian distribution.
\end{abstract}

Key Words: Bufo boreas, Western Toad, Pseudacris maculata, Boreal Chorus Frog, Rana luteiventris, Columbia Spotted Frog, Rana sylvatica, Wood Frog, amphibian, Yukon, distribution.

Biological surveys began in the interior of the Yukon Territory in 1899 (Osgood and Bishop 1900); however, these were often directed at mammals and birds, and did not report amphibian observations. The earliest known amphibian records for the region are from Atlin (Slevin 1928; Western Toad and Wood Frog) and Bennett Lake, British Columbia (Logier 1932; Columbia Spotted Frog, formerly Western Spotted Frog). The first published report of amphibians in the Yukon was by Loomis and Jones (1953), who reported a Wood Frog collected at Dezadeash Lake in 1948 by the University of Kansas Museum of Natural History. Museum collections from the Canadian Museum of Nature $(\mathrm{CMN})$ and the American Museum of Natural History (AMNH) date to 1933 and 1936, respectively. Logier and Toner (1961) report only the single locality record of Loomis and Jones (1953). Using an expanded database, including museum specimens and inferences from locality records in Alaska, the Northwest Territories and British Columbia, Martof (1970) shows an approximate range for the Wood Frog; although a large area with no data existed in the eastern and northern Yukon. The amphibian range maps in Stebbins (2003) were modified with information provided by BGS.

The Western Toad (Bufo boreas) was first observed in 1961 in the southeast Yukon (Cook 1977). The Columbia Spotted Frog was first observed in 1993 (Mennell 1997) in the southwest Yukon. There are no published records of the Boreal Chorus Frog or other species for the Yukon. All species of amphibians have been underrepresented in records due to the remoteness of breeding sites and lack of directed surveys. Several amphibian surveys and expert observations have been made since 1993 by the authors and others, and the data have remained unpublished. We typically used visual encounter surveys and dipnetting of terrestrial, semi-terrestrial (wetland) and aquatic habitats (Thoms et al. 1997). We review unpublished data, unpublished reports and museum collections to present an update on the amphibian species of the Yukon and their ranges. Anecdotal information on phenology and habitats is provided. Scientific and common names follow Collins and Taggart (2002).

\section{Species Accounts}

WESTERN TOAD (Bufo boreas)

Western Toads occur from south-coastal Alaska, through western Canada and the western United States to Baja California. Cook (1977) reported two museum specimens of the Western Toad from the Yukon. The Whitehorse specimen, collected in 1948, was verified in 1997 by F. Cook, who also verified the label in 2003 as collected by William Mason July 1-10. Mason was an entomologist and the date notation suggests a specimen taken in a pan or similar trap set for that period and contents preserved on the last date (F. Cook, personal communication). This specimen is here considered to be either an extra-limital stray or erroneously labelled, since the nearest confirmed breeding records of Western Toads are $100 \mathrm{~km}$ to the south in British Columbia on Bennett Lake (Slough 2004*; $17 \mathrm{~km}$ from the British Columbia-Yukon border) and on Tagish Lake (Mennell and Slough 1998*; $40 \mathrm{~km}$ from the border). A single adult was found in nonbreeding habitat on Tagish Lake $9 \mathrm{~km}$ from the border (Mennell and Slough 1998*). All other records are from the Liard Basin in the southeast Yukon, where the Western Toad is now known from at least 11 populations in five geographically separated areas (Figure 1). These are summarized from west to east.

Two adult Western Toads were observed near a geothermal spring on the Meister River $\left(60^{\circ} 17^{\prime} \mathrm{N}\right.$, $130^{\circ} 07^{\prime} \mathrm{W}$ ) in 1988 (D. Mossop, personal communi- 
cation). RLM searched this area in 2004 but did not observe Western Toads. A single adult was observed near Upper Liard $\left(60^{\circ} 05^{\prime} \mathrm{N}, 128^{\circ} 58^{\prime} \mathrm{W}\right)$ in 2004 (C. Eckert, personal communication; verified from photographs).

At least six breeding populations of Western Toads occur in close proximity (within $16 \mathrm{~km}$ ) on the lower Coal River and wetlands to the west. The most visited population and breeding site is the Coal River Springs $\left(60^{\circ} 09^{\prime} \mathrm{N}, 127^{\circ} 26^{\prime} \mathrm{W}\right)$. G. Scotter collected two specimens in 1977 (CMN 17798-1 and -2), and at least six Western Toad records of adults and metamorphs were documented between 1982 and 2004 (B. Slough and L. Mennell, unpublished data; Slough 2005a*). Two breeding sites exist in spring marshes below the upper and lower springs. The temperature of the main source pool is $11^{\circ} \mathrm{C}$, likely maintaining frost-free hibernating sites nearby. Other breeding sites occur in riparian floodplain backwater channels and ponds above the springs $\left(60^{\circ} 11^{\prime} \mathrm{N}, 127^{\circ} 29^{\prime} \mathrm{W}\right)$, below the springs on an island in the Coal River $\left(60^{\circ} 07^{\prime} \mathrm{N}, 127^{\circ} 24^{\prime} \mathrm{W}\right)$, and further downstream on the Coal River in a bedrock pool $\left[60^{\circ} 08^{\prime} \mathrm{N}, 127^{\circ} 14^{\prime} \mathrm{W}\right]$ (J. Staniforth and J. Meikle, personal communication; L. Mennell, unpublished data; Slough 2005a*). Juvenile toads have also been observed in the chain of lakes southwest of the springs $\left(60^{\circ} 14^{\prime} \mathrm{N}, 127^{\circ} 29^{\prime} \mathrm{W}\right)$ [B. Slough, unpublished data; Slough $2005 \mathrm{a}^{*}$ ] and in a tributary of the lakes $\left(60^{\circ} 06^{\prime} \mathrm{N}\right.$, $127^{\circ} 32^{\prime} \mathrm{W}$ ) [Slough $2005 \mathrm{~b}^{*}$ ], suggesting the presence of breeding populations.

Cook (1977) reported a specimen collected in 1961 from North Toobally Lake $\left(60^{\circ} 20^{\prime} \mathrm{N}, 126^{\circ} 15^{\prime} \mathrm{W}\right)$. An adult Western Toad was observed $23 \mathrm{~km}$ to the south near South Toobally Lake $\left(60^{\circ} 08^{\prime} \mathrm{N}, 126^{\circ} 19^{\prime} \mathrm{W}\right)$ in 1996 (C. Eckert, H. Grunberg, P. Sinclair, personal communication; verified from photograph). A single adult Western Toad was observed on the lower Beaver River [6002'N, 124³2'W] in 1997 (B. Bennett, V. Loewen, J. Staniforth, personal communication; verified from photograph). All of the Western Toad localities are low elevation sites with early deep snow accumulation. The snow cover likely prevents deep frost penetration and permits safe hibernation, as speculated by Cook (1977).

Western Toad breeding sites are predominantly shallow, silty areas on ponds, lakes and rivers. Adults are often encountered far from water in forests or meadows. Breeding dates in the Yukon are unknown; however, populations in northwestern British Columbia breed in late May (B. Slough and L. Mennell, unpublished data). A population in the Atlin Warm Springs, $20 \mathrm{~km}$ south of Atlin, breeds in late February-early March. Tadpoles have been observed on the Coal River in July, and tadpoles and metamorphs were observed there on 10 August 2004.

\section{Boreal Chorus Frog Pseudacris maculata}

While Pseudacris maculata is currently considered a distinct species following Platz (1989), it was formerly called $P$. triseriata maculata (and earlier Pseudacris triseriata septentrionalis). Recent phylogeographic studies of North American chorus frogs have shown that range limits and taxonomy of the triseriata complex may need revision (Moriarty and Cannatella 2004). The Boreal Chorus Frog ranges across much of central North America east of the continental divide, from the Northwest Territories to southern James Bay and south to Arizona and New Mexico. We present the first records of the Boreal Chorus Frog from the Yukon. Boreal Chorus Frog calls were identified at five natural wetlands and roadside/airstrip ditches along a $10 \mathrm{~km}$ section of road and airstrip in the lower La Biche River valley in the southeast Yukon $\left(60^{\circ} 03^{\prime} \mathrm{N} 123^{\circ} 58^{\prime} \mathrm{W}\right.$ to $60^{\circ} 08^{\prime} \mathrm{N} 124^{\circ} 03^{\prime} \mathrm{W}$ ) between 8 and 17 June in 1995 , 1997 and 1999 (Figure 1) [B. Bennett, C. Eckert, V. Loewen, P. Sinclair, J. Staniforth, personal communication; B. Slough, unpublished data]. BGS also identified Boreal Chorus Frog tadpoles there on 10 June 1999. Extensive surveys by the authors in southeastern Yukon in 2004 did not yield any further observations of the species. Matsuda et al. (2006) show the species $160 \mathrm{~km}$ to the southeast at Fort Nelson, British Columbia, and it occurs $125 \mathrm{~km}$ northeast at the junction of the South Nahanni and Liard rivers (Fournier 1998*).

\section{Columbia Spotted Frog (Rana luteiventris)}

The Columbia Spotted Frog occurs between the Rocky Mountains and Coast Ranges from the Yukon to Utah and Nevada in the south. Mennell (1997) located two populations of Columbia Spotted Frogs adjacent to the West Arm of Bennett Lake in 1993, in a pond $\left(60^{\circ} 05^{\prime} \mathrm{N} 135^{\circ} 01^{\prime} \mathrm{W}\right)$ and a beaver pond on a creek $\left(60^{\circ} 01^{\prime} \mathrm{N} 135^{\circ} 12^{\prime} \mathrm{W}\right)$ [Figure 1]. Slough (2002) obtained single voucher specimens and preserved toetips (for phylogeographic studies, $\mathrm{n}=10$ and 11 , respectively) from the two ponds in 2001 (Slough et al. 2002*). A third population was found in a beaver pond in the same area (Slough 2002) [6003'N 134 $58^{\circ}$ 'W] where a voucher specimen and six toe-tips were obtained; specimens are held at the Redpath Museum, McGill University [RM 3382, 3379 and 3381 for the three populations, respectively]. Additional Columbia Spotted Frog adults ( $n=7$ in 4 sites) were observed within $2.5 \mathrm{~km}$ of Site 2 in apparent non-breeding habitats (i.e., early life-stages not observed) along the Partridge River to Bennett Lake (R. McClure, personal communication, verified from photograph; B. Slough and L. Mennell, unpublished data). These three breeding populations are the most northerly of a series of populations that extends into northwestern British Columbia (Matsuda et al. 2006, Mennell 1997; Mennell and Slough 1998*; Slough et al. 2002*).

In 2003, two adult Columbia Spotted Frogs were observed in Irons Creek Lake in the southeastern Yukon $\left(60^{\circ} 00^{\prime} \mathrm{N} 127^{\circ} 05^{\prime} \mathrm{W}\right.$; P. Hovingh, personal communication to Yukon Fish and Wildlife Branch) (Figure 1). Several adults, juveniles and one egg mass were observed in 2004 and 2005 (Slough 2005b*). The long- 


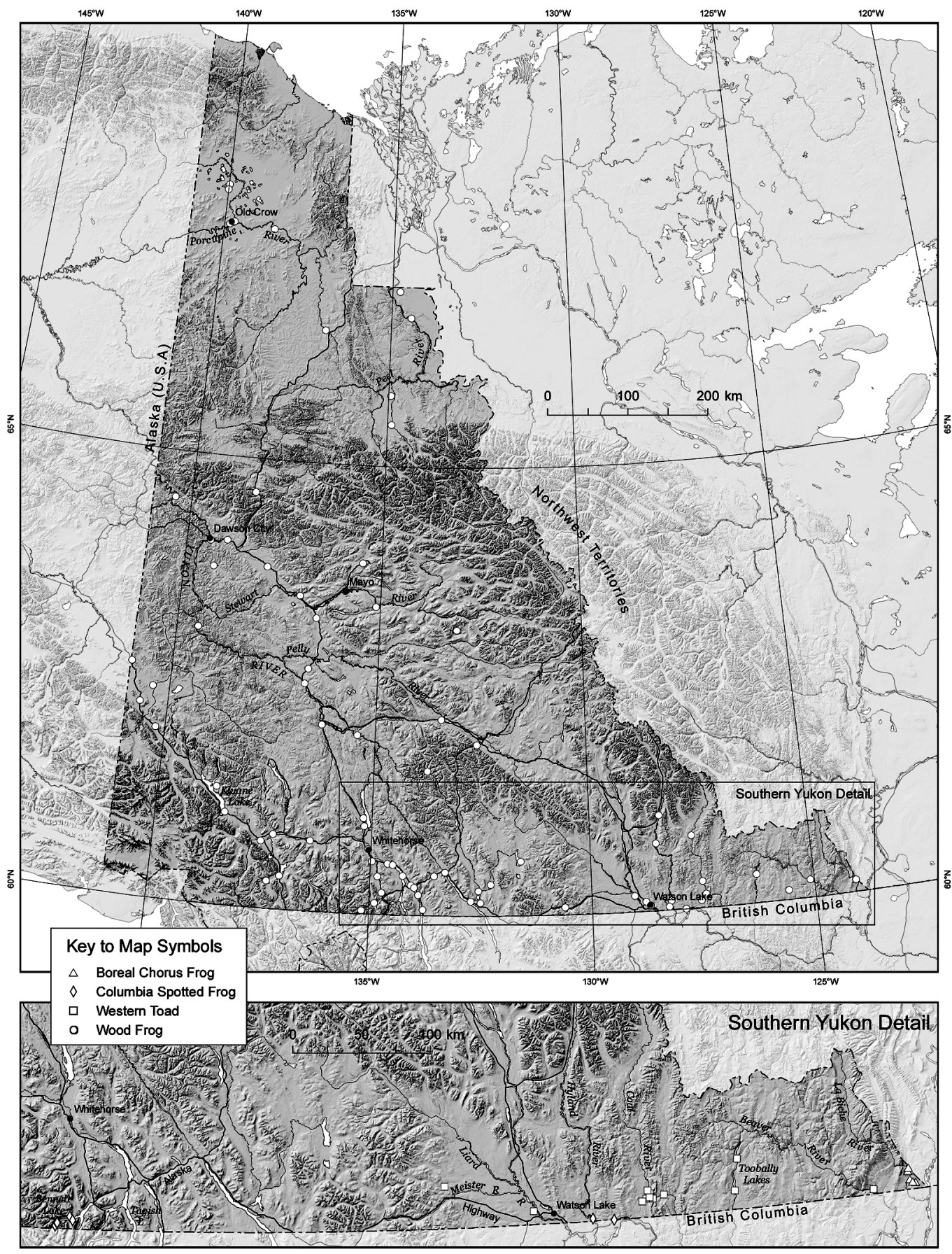

FIGURE 2. Distribution of amphibians in the Yukon. Refer to text for data sources. Shaded areas are mountain ranges. 
term prospects of this population are unknown as this small lake has regularly been stocked with Rainbow Trout (Oncorhynchus mykiss) since 1990, with the latest stocking occurring in 2003 (D. Toews, personal communication). Rainbow trout are known to prey on Columbia Spotted Frog tadpoles and juveniles, which overwinter in lakes (Pilliod and Peterson 2000). Furthermore the heavily forested shoreline habitat is atypical for Columbia Spotted Frogs (Ovaska 1999*). The species has been observed only on human-altered shoreline which has been cleared of trees and graded into Irons Creek Lake, creating shallows. In 2004, RLM observed an adult Columbia Spotted Frog 15 km west of this site on an ox-bow channel of the Hyland River $\left(60^{\circ} 01^{\prime} \mathrm{N} 127^{\circ} 12^{\prime} \mathrm{W}\right)$.

The Columbia Spotted Frog localities in the Liard Basin and Coast Mountain Cordillera are in areas with early deep snow accumulation which likely prevents thick ice formation and permits safe aquatic hibernation.

Columbia Spotted Frogs were noticeably abundant in and around pond outlets, where they were invariably perched at the waters edge. Breeding and transformation dates in the Yukon are unknown; however populations in nearby northwestern British Columbia have been observed extensively (Mennell 1998*; B. Slough, unpublished data). Breeding takes place on a single warm day from 18-22 May (six years of observations) in traditional shallow basins along the margins of ponds. Some of the ponds may be partially ice-covered with melting snow surrounding the ponds. They breed communally with up to 30 individuals congregating in a few square metres. Males begin calling above water over a larger area and finally call underwater as the aggregation consolidates and begins amplexis, leaving a mass of egg clutches unattached in shallow water. Breeding sites are occasionally compromised by falling water levels, leaving egg masses landlocked and stranded. Tadpoles are free-swimming in 14-16 days and metamorphs appear on pond edges throughout August (Mennell 1998*). Metamorphs have also been observed in late May, and tadpoles have been observed in midSeptember at higher elevation ponds, suggesting that some tadpoles overwinter.

\section{WoOd Frog (Rana sylvatica)}

The Wood Frog ranges from northern Alaska and the Yukon through most of Canada below treeline east to the Atlantic and south to the Appalachian Mountains. Disjunct populations occur in several states south of this range. Numerous collections and observations reveal that Wood Frogs are common and abundant in wetlands across the Yukon below the arctic and alpine treeline (B. Slough, unpublished data) [Figure 1]. The most northerly location is Ney Khwi Vun ("Frogs in the Lake"), on the Old Crow Flats $\left(68^{\circ} 01^{\prime} \mathrm{N} 140^{\circ} 05^{\prime} \mathrm{W}\right.$; Gray and Alt 2000*). Museum collections exist in the University of Kansas Museum of Natural History $(\mathrm{n}=1)$, the American Museum of Natural History ( $\mathrm{n}$
$=16)$, the Canadian Museum of Nature $(n=56)$ and the Auke Bay Laboratory, Alaska Fisheries Science Center (Hodge 1976; $n=2$ ). One of the museum specimens from mouth of Coal Creek (AMNH 44751) was originally misidentified as Pseudacris septentrionalis (now P. maculata) until verification as a Wood Frog in 1995 by L. S. Ford Curatorial Associate, AMNH (F. Cook, personal communication to P. Milligan). In July 2000, BGS obtained Wood Frog samples for phylogeographic studies (J. Irwin and J. Lee-Yaw, unpublished data); eight juveniles from Nogold Creek, west of Mayo $\left(63^{\circ} 26^{\prime} \mathrm{N} 135^{\circ} 06^{\prime} \mathrm{W}\right)$, and 10 juveniles from south of Whitehorse $\left(60^{\circ} 35^{\prime} \mathrm{N} 134^{\circ} 58^{\prime} \mathrm{W}\right)$. The CMN also has tissue from 11 adults and 25 juveniles from "Paddy's Pond", Whitehorse, July and August 1992 by Gerry Whitley.

The Wood Frog specimens and observations (Figure 1) document an extensive range for the species in the Yukon. Most observations are from road and river access corridors, and gaps in the range exist in inaccessible areas. We believe that the species occupies suitable habitats below treeline within these gaps. Furthermore, the distribution is continuous in areas of extensive wetlands such as the Whitehorse area, where only a small sample of locations was plotted. Yukon Wood Frogs were assigned to the Alaskan phenotype by Martof and Humphries (1959). While we have no data on most visible characters used to differentiate the types, there is a north-south gradient in the frequency occurrence of the mid-dorsal stripe, from approximately $100 \%$ in the north and central Yukon to $50 \%$ or less in the south.

Wood frogs breed in the Yukon as soon as shorelines become ice-free in late April-early May. They breed over a period of up to two weeks, they are frequently solitary breeders, and they do not necessarily use traditional breeding sites, but use any site with shallow water and sparse emergent grass or sedge vegetation. Egg masses are attached singly to grass or sedge stalks. Metamorphs move onto land throughout July. The most common Wood Frog breeding habitats are shallow, permanent and fishless ponds.

\section{Neighbouring Species}

Three species of salamanders occur near the southwestern Yukon, but have yet to be recorded there. The Long-toed Salamander (Ambystoma macrodactylum) ranges as far north as the Taku River (Hodge 1976; P. Milligan, personal communication; Mennell and Slough 1998*) and upstream to the junction of the Nakina and Sloko rivers (K. Heinemeyer, personal communication), $110 \mathrm{~km}$ from the British ColumbiaYukon border (observation not shown by Matsuda et al. 2006). The Northwestern Salamander (Ambystoma gracile) and Roughskin Newt (Taricha granulosa) occur in Southeast Alaska (MacDonald 2003), but they occupy Pacific coastal habitats not present in the Yukon. 


\section{Future Surveys}

Dedicated amphibian surveys and expert observations have greatly increased our knowledge of the species and their ranges in the Yukon. We presented significant new observations of Western Toads, Columbia Spotted Frogs and Wood Frogs for the Yukon, and the first records of Boreal Chorus Frogs. Continued efforts should identify additional populations, their degree of isolation and habitat requirements; all necessary for conservation planning. The ranges of the Western Toad, Columbia Spotted Frog and Boreal Chorus Frog in the Yukon imply data deficiencies for these species in northern British Columbia. The Columbia Spotted Frog is common on Atlin Lake, south of Atlin (Slough et al. 2002*; not shown by Matsuda et al. 2006).

\section{Acknowledgments}

Funding to BGS and RLM for field surveys was provided by NatureServe Yukon, Yukon Department of Environment; and by Northern Research Endowment Grants from the Northern Research Institute, Yukon College. Canadian Parks and Wilderness Society-Yukon Chapter kindly supported BGS on several wilderness trips. We are grateful to the many individuals who reported amphibian sightings. Significant Wood Frog sightings were reported by D. Mossop, J. Meikle, L. Karnis, M. Gill, R. Lamb and G. Whitley. E. Wind and T. Jung reviewed earlier versions of the manuscript. G. Perrier of Dragonfly Maps provided digital cartographic design of the distribution map. We thank P. Milligan for his work as the founding Yukon DAPCAN coordinator.

Documents Cited [marked $*$ in text citations]

Fournier, M. 1998. Amphibians \& reptiles in the Northwest Territories. A brochure prepared for Ducks Unlimited, Environment Canada, Indian and Northern Affairs Canada, and Northwest Territories Resources, Wildlife and Economic Development, Yellowknife, Northwest Territories. Ecology North, Yellowknife.

Gray, D. R., and B. T. Alt. 2000. Resource description and analysis of Vuntut National Park of Canada. Western Canada Service Centre, Parks Canada, Vancouver, British Columbia. 650 pages.

Mennell, R. L. 1998. The ecology and population status of the Columbia spotted frog (Rana luteiventris) at their northern range limit. Prepared for the Northern Research Institute, Yukon College, Whitehorse. 21 pages.

Mennell, R. L., and B. G. Slough. 1998. Amphibian and biodiversity inventories of ecoregions in northwestern British Columbia. Habitat Conservation Trust Fund Project TF28056. Ministry of Environment, Lands and Parks, Victoria, British Columbia. 86 pages.

Ovaska, K. E. 1999. Status report on the Columbia spotted frog, Rana luteiventris, in Canada. Committee on the Status of Endangered Wildlife in Canada. 55 pages.

Slough, B. G. 2004. Western toad inventory in the Chilkoot Trail National Historic Site, July-August 2004. Parks Canada Species at Risk Inventory Fund Project SARINV04-30. 54 pages.
Slough, B. G. 2005a. Western toad, Bufo boreas, stewardship in the Yukon. NatureServe Yukon, Whitehorse. 26 pages.

Slough, B. G. 2005b. Assessment of the Impact of Rainbow Trout Introductions on Columbia Spotted Frogs in Irons Creek Lake, Yukon. Fish and Wildlife Branch, Yukon Department of Environment, Whitehorse. iv +17 pages.

Slough, B. G., J. T. Irwin, and D. M. Green. 2002. Postglacial Colonization and Genetic Diversity of the Columbia Spotted Frog at its Northern Range Limit. Progress report, prepared for the Northern Research Institute, Yukon College, Whitehorse. 12 pages.

\section{Literature Cited}

Collins, J. T., and T. W. Taggart. 2002. Standard common and current scientific names for North American amphibians, turtles, reptiles and crocodilians, fifth edition. Center for North American Herpetology. 45 pages.

Cook, F. R. 1977. Records of the boreal toad from the Yukon and northern British Columbia. Canadian FieldNaturalist 91: 185-186.

Hodge, R. P. 1976. Amphibians and reptiles in Alaska, the Yukon, and Northwest Territories. Alaska Northwest Publishing Co., Anchorage, Alaska. 89 pages.

Logier, E. B. S. 1932. Some accounts of the amphibians and reptiles of British Columbia. Contribution Number 5, Royal Ontario Museum of Zoology. Reprinted from Transactions of the Royal Canadian Institute, Volume XVIII, Part 2: 311-338.

Logier, E. B. S., and G. C. Toner. 1961. Check list of the amphibians and reptiles of Canada and Alaska, a revision of Contribution Number 41. Royal Ontario Museum, Contribution Number 53 . viii +92 pages.

Loomis, R. B., and J. K. Jones, Jr. 1953. Records of the wood frog, Rana sylvatica, from western Canada and Alaska. Herpetologica 9: 149-151.

MacDonald, S. O. 2003. The amphibians and reptiles of Alaska: a field handbook. Version 1.0, U.S. Fish and Wildlife Service, Juneau, Alaska, and University of Alaska Museum, Fairbanks, Alaska. 45 pages.

Martof, B. S., and R. L. Humphries. 1959. Geographic variation in the wood frog Rana sylvatica. The American Midland Naturalist 61: 350-389.

Martof, B. S. 1970. Rana sylvatica Le Conte, Wood Frog. Catalogue of American Amphibians and Reptiles 86: 1-4.

Matsurla, B. M., D. M. Green, and P. T. Gregory. 2006. The amphibians and reptiles of British Columbia. Royal British Columbia Museum Handbook. 266 pages.

Mennell, L. 1997. Amphibians in southwestern Yukon and northwestern British Columbia. Herpetological Conservation 1: 107-109.

Moriarty, E. C., and D. C. Cannatella. 2004. Phylogeographic relationships of the North American chorus frogs (Pseudacris: Hylidae). Molecular Phylogenetics and Evolution 30: 409-420.

Osgood, W. H., and L. B. Bishop. 1900. Results of a biological reconnaissance of the Yukon River region. North American Fauna Number 19: 1-100.

Pilliod, D. S., and C. R. Peterson. 2000. Evaluating effects of fish stocking on amphibian populations in wilderness lakes. Pages 328-335 in Wilderness Science in a Time of Change Conference Volume 5: Wilderness Ecosystems, Threats, and Management; May 23-27, 1999, Missoula, Montana. Compiled by D. N Cole, S. F. McCool, W. T. Borrie and J. O'Loughlin. Proceedings RMPS-P15-VOL-5. 
Rocky Mountain Research Station, U.S. Department of Agriculture, Odgen, Utah.

Platz, J. E. 1989. Speciation within the chorus frog, Pseudacris triseriata: morphometric and mating call analyses of the boreal and western subspecies. Copeia 1989: 704-712.

Slevin, J. R. 1928. The amphibians of western North America. Occasional Papers of the California Academy of Sciences XVI. 152 pages.

Slough, B. G. 2002. Geographic distribution: Rana luteiventris. Herpetological Review 33: 146.
Stebbins, R. C. 2003. A field guide to western reptiles and amphibians. Third edition. Houghton Mifflin Company, Boston, New York. xiii +533 pages.

Thoms, C., C. C. Corkran, and D. H. Olson. 1997. Basic amphibian survey for inventory and monitoring in lentic habitats. Pages 35-46 in Sampling amphibians in lentic habitats. Edited by D. H. Olson, W. P. Leonard and R. B. Bury. Northwest Fauna Number 4: 1-134. Society for Northwestern Vertebrate Biology, Olympia, Washington.

Received 10 March 2005

Accepted 30 November 2005 
Bill started as an assistant with the Canada Department of Agriculture in Ottawa. Twenty-one years later in 1967 he was made a Research Scientist. This classification was generally reserved for people who had a Ph.D., but Bill's outstanding accomplishments at that time were judged by his colleagues and the science arm of the federal civil service to warrant treatment at the Ph.D. level. The awards that Bill has received since then are numerous, but one in particuar draws attention his broad contribution. In November 2002 he received a Queen's Golden Jubilee Commerorative Medal. These medals were awarded to a limited number of people who have made a significant contribution to Canada, in this case "especially for his work on The Canadian Field-Naturalist, Canada's foremost scientific journal for field biology.” Bill has served as the business manager, article and book review contributor, and manuscript reviewer for this journal for 60 years, and his influence on its development, support, improvement and content is beyond question.

Bill also served as curator of the largest dried plant collection in Canada from 1959 to 1988 and was largely responsible for its development. This collection of now over 1 million specimens has become a major tool of Agriculture and Agri-food Canada for plant identification. This collection provides a wealth of informa- tion that is needed to implement Agriculture and Agrifood Canada's Biodiversity Strategy and to respond to the International Convention on Biodiversity. It is particularly valued as a tool for improved plant classification studies used by researchers in other institutions both in Canada and worldwide. It is also important in protecting Canada's borders and enforcing federal regulations. Many thousands of specimens that Bill collected in the northern wilderness under extreme and dangerous conditions are part of this collection and serve as vouchers for his numerous publications and books.

Bill was born in Hamilton on 2 December 1922. His father was a doctor and his mother a nurse at Hamilton General. He grew up in Hamilton and received his B.A. from McMaster University in 1946.

The Yukon Biodiversity Awareness Award plaque that Bill received included a photo of one of Yukon's rarest plants, McBride's Phacelia (Phacelia mollis) which is a Beringian endemic (confined to the unglaciated area of Alaska and Yukon).

Text slightly modified from that provided courtesy of Paul Catling, Canada Agriculture and Agri-food, Ottawa. Photograph of the award plaque courtesy Stephen Daryshire, Canada Agricuture and Agri-food, Ottawa.

\section{Errata The Canadian Field-Naturalist 120(1)}

Book Review. Lapland a Natural History, pages 123-124: replace "Redcliff” and Redcliffe" with Ratcliffe, throughout.

\section{Articles.}

Diversity and range of amphibians and reptiles of the Yukon Territory. Brian G. Slough and R. Lee Menell in Literature Cited page 91 "Matsurla" should read Matsuda.

Recent Declines of House Sparrows, Passer domesticus, in Canada's Maritime Provinces. Anthony J. Erskine. Page 48 insert following Dunn et al.

Erskine, A. J. 1980. A House Sparrow die-off. Nova Scotia Bird Society Newsletter 22: 183-184.

For reference following Erskine 1992b insert Erskine before initials. 